KAI HORSTHEMKE

Catholic University of Eichstätt-Ingolstadt

Eichstätt-Ingolstadt

Germany
Forum Pedagogiczne $9(2019) 1$

Wpłynęło: 21.02.2019

Zatwierdzono do druku: 24.04.2019 DOI: $10.21697 /$ fp.2019.1.17

\title{
THINKING WITHOUT HEIDEGGER?
}

\begin{abstract}
There has been a resurgence of Martin Heidegger's ideas in recent years, especially within English-language philosophy of education. Yet, there have also been other developments that deserve to be taken seriously, first and foremost the indication that his anti-Semitism informs not only his personal beliefs and political stance but is already rooted in his philosophy, notably his ontology. It is these developments and the context of Heidegger's philosophy that are examined first, before I return to the purported significance of his ideas for education towards the end of this essay.
\end{abstract}

Key words: Martin Heidegger; anti-Semitism; ethnonationalism; philosophy of education.

\section{Heidegger and anti-Semitism}

It is a well-known and much-publicised fact that Martin Heidegger was not only an opportunist Nazi sympathiser but also a life-long anti-Semite who never apologised for his proclivities and actions during the Third Reich or renounced his anti-Jewish ideas or beliefs. After 1945, he never commented directly on the Holocaust but was concerned instead with downplaying his involvement with National Socialism in Germany. Although he became evidently disillusioned with the actual movement of National Socialism, with Nazism, coming to perceive it not as the new beginning he had initially anticipated but rather, after a while, as a species of technological nihilism, he never broke with some of its central ideas and biases.

Following the publication of Heidegger's Einführung in die Metaphysik in 1953, Jürgen Habermas published an intriguing proposal: to think with Heidegger against Heidegger (Habermas, 1953). In recent years, particularly in response to the phased appearance of Heidegger's Schwarze Hefte (Heidegger, 2014; 2015), a new development has taken place in Germany: articulation of the need to think without Heidegger. Although this turn of events has not come as much of a surprise, Heidegger scholarship has until recently been insistent on a strict separation 
of the man and his œuvre. As Michael Inwood writes (1997, p. 129) in his short introduction to Heidegger: "What does [his entanglement with Nazism] tell us about his philosophy? And conversely, what does his philosophy tell us about it? Not much." And when he assumes that "the ideas of [Being and Time] did not commit Heidegger to Nazism" (ibid, p. 130), it turns out that he may be quite wrong in both regards.

Before the publication of Heidegger's notebooks ${ }^{1}$, it was his letters to his wife Elfride (Heidegger, 2008) and to his brother Fritz (now collected and annotated in: Homolka, Heidegger [eds.], 2016) that confirmed the German philosopher's lasting anti-Semitism and ethnonationalism. In what follows, 'anti-Semitism' will be used to mean hostility towards or prejudice against Jews. It does not imply any rejection of the state of Israel or hostility towards the Israeli government - although these two attitudes often coincide. A corollary of this understanding is that one can be vehemently opposed to anti-Semitism without thereby endorsing the actions or policies of the Israeli government. That is to say, being critical of the government of Israel does not connote anti-Semitism. This is a distinction that, regrettably, is often not made - notably (and for obvious historical reasons) by the present German government. 'Ethnonationalism', in Heidegger's case, means German ethnic nationalism. For Heidegger, whiteness (being white) is a necessary but not sufficient condition for national (in this case German) identity. All Germans are white, in other words, but not all whites are German (Heidegger, 2014: Schwarze Hefte/Überlegungen III, section 195).

This ethnonationalism also has implications for philosophy. For Heidegger, the two truly philosophical languages are ancient Greek and German. Ancient Greek language and culture gave us the beginning of Western philosophy, while German language and culture gave us a new beginning that would re-root Western man. Heidegger's anti-Jewish outlook and initial pro-Nazi sympathies (shared by Elfride, but not by Fritz) were never recanted. Heidegger's actual involvement with Nazism may not have lasted very long, but his contributions included a program of Gleichschaltung, of cooptation or forcible-coordination, which aimed at bringing all aspects of German life, not least German academic life, into line with the ideals of the National Socialist state; the banning of Jewish student societies; introduction of proof of the Aryan certificate and fatigue duty; introduction of the Hitler salute at Freiburg university; the firing of academics on the basis of race membership; and withdrawal of teaching permission for Jewish lecturers. Unlike his "brief involvement or at least flirtation with Nazism" (Heil, 2011, p. 8), a relationship that received unequivocal articulation in his rectoral address on his investiture at the University of Freiburg in April $1933^{2}$, his anti-Semitism was life-long.

1 Heidegger referred to these as his "Denktagebuch", a diary meant to track his thinking.

2 Concerning Heidegger's rectoral address on his investiture at the University of Freiburg, Die Selbstbehauptung der deutschen Universität ("The self-affirmation of the German university"; 
On 17 October 1918, Heidegger writes to Elfride: "people have been systematically nauseated by pan-German pipe dreams [...]. I myself recognize ever more urgently the necessity for leaders" (Heidegger, 2008, p. 55). In a lecture addressed to students at the beginning of the winter semester 1933-34, he articulates his confidence that the National Socialist revolution will bring on a "complete revolution of our German Dasein": "You should not allow axioms and ideas to regulate your lives. The Führer, and he alone, is the present and future reality and law of Germany"3 (quoted in: Gerratana, 1977, p. 52; see also Vašek, 2014, p. 72). Equally chilling is a letter dated 18 October 1916 (Heidegger, 2008, p. 28): “The jewification of our culture \& universities is certainly horrifying \& I think the German race should summon up the inner strength to find its feet again". ${ }^{4}$ On 20 August 1920 he comments, in anticipation of rising prices at the imminent harvest dance, that "the farmers are gradually getting insolent up here too \& [that] everything's swamped with Jews and black marketeers" (Heidegger, 2008, p. 77). In a letter to his brother Fritz dated 13 April 1933, Heidegger complains that the disappearance of three Jews from his university department, for reasons of the so-called Beamtengesetz (or public service law), will leave him having to do all the work (Homolka \& Heidegger, 2016, p. 35). After the end of the war (23 July 1945), he informs Fritz and his family that everything is worse than it was during the time of the Nazis: "Hier ist es wenig schön. Wir müssen KZ-Leute in die Wohnung aufnehmen"5 (Homolka, Heidegger, 2016, pp. 126-127). None of the letters to his wife and to his brother deal with the persecution of Jews during the Third Reich. The Schwarze Hefte, however, do contain references to terror, mass annihilation and concentration camps, albeit in terms of analogies that betray a staggering paucity of ethical and

Heidegger, 1983), his former colleague Karl Jaspers (who was a professor of philosophy at the University of Heidelberg, before being dismissed by the regime in 1937 for having a Jewish wife) commented later: "In form it was the typical academic speech, but in its content it represented neither more nor less than a Nazi programme for university reform" (quoted in Trewhela, 2008). Heidegger's involvement with National Socialism was unmissable even prior to his investiture: "(1) Nazi students filled Heidegger's classes and enthusiastically clamoured around him; (2) Heidegger's wife was an enthusiastic member of the party and supporter of national socialism; (3) at the Davos debate with [German Jewish philosopher] Ernst Cassirer in 1929, Nazi students supported Heidegger and shouted down Cassirer with slogans and insults; and (4) Heidegger's lifestyle and thinking were sympathetic to fascist völkisch [folksy] ideology: he wore Bavarian peasant clothes and affected peasant manners; he spent as much time as possible in his mountain retreat in Todtnauberg; and he was becoming increasingly nationalistic and political in the 1930s." (Kellner, 1984, pp. 406-407n.3/ch.4)

3 "Nicht Lehrsätze und 'Ideen' seien die Regeln eures Seins. Der Führer selbst und allein ist die heutige und künftige Wirklichkeit und ihr Gesetz." (Aufruf an die Deutschen Studenten. Freiburger Studentenzeitung; 3 November 1933)

4 In the English translation of the letters, the ampersand has been used to replicate Heidegger's use of "u." (as an abbreviation of "und").

5 "It is hardly nice here at all. We have to put up concentration camp people." 
political judgement. Thus, Heidegger (2015, p. 59) considers the "terror of ultimate nihilism" to be even more sinister than the "massiveness of executioners and $\mathrm{KZ}$ [concentration camps]". He compares "the noise over the deaths of the many" to the fact that Leibniz has fallen into oblivion and that Nietzsche has been done wrong, the result being that standards or yardsticks have been lost in the evaluation and assessment of irresponsibility.

The 'new development' to which I referred above resulted from the general realisation that it was not only a matter of personal opinion or political idiosyncrasy: Heidegger's nationalism and racism arguably went even deeper.

Should we cease engaging with the ideas and texts of those who have been demonstrated, quite unequivocally, to have manifested prejudicial leanings and convictions? Gottlob Frege was a brilliant logician and philosopher of mathematics. He was also a well-known nationalist and anti-Semite. Yet, any dismissal of his contributions to logic and the philosophy of mathematics on the mere basis of his racist prejudices (that is, as opposed to being based on lack of philosophical rigour, coherence or plausibility) would involve an ad hominem fallacy. In the case of Frege (as in the case of Aristotle, an apologist of slavery), it is presumably advisable to draw a distinction between 'person' and 'work'. With Heidegger, however, it is a different matter. Heidegger's anti-Semitism arguably and demonstrably pervades his philosophy, notably his ontology (see, for example, Heidegger, 2001). Heidegger's ethnonationalist prejudice (which is not mitigated by his four-yearaffair in the 1920 s with his Jewish student Hannah Arendt ${ }^{6}$ ) is structural. This has led some (see, for example, Di Cesare, 2015; Heinz, 2015; Noll, 2016; Vašek, passim; see also Blum, 2014; Cammann \& Soboczynski, 2016; Neiman, 2016; Probst, 2015, and the anthologies edited by Heinz and Kellerer, and by Homolka and Heidegger's grandson Arnulf Heidegger, both 2016) to call for a more radically dismissive approach towards the philosopher.

\section{Dasein}

What is the substance of the claim that Heidegger's anti-Semitism is rooted in his ontology?

At the core of his philosophy is the theme of being (Sein). Although it is the central if not the only philosophical question for Heidegger, it has-he assertspassed into oblivion. His endeavour is to discover the reasons for this oblivion of being, how it has taken place, where it has led us, and-importantly-how we can regain access to being. Dasein, 'being there', is a term employed by Heidegger in the investigation of human existence, that is, of the type of being humans have. There is a distinction between 'existence' and 'being': of all that exists, it is humans

6 See also Ettinger, 1995.

7 Dasein refers both to the (concrete) human being and to (abstract) human existence. 
who have characteristically always apprehended 'being', however vaguely. Human 'being' is Dasein, 'being there', 'in the world'. (This is the initial constitutive feature of human Dasein, its 'facticity.") The world is conceived and conceptualised as structurally differentiated into regions. Heidegger refers to these fundamental structures of human Dasein as 'existentials' (Existenzialien, existential modalities and their modifications; broadly comparable to what Aristotle and Kant have referred

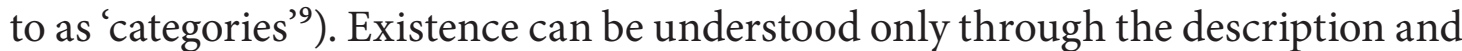
analysis of human 'being', Dasein, the basic mode of being in the world through involvement and participation. The environment or surrounding world (Umwelt) is constituted of objects that are accessible and utilisable for purposive action. Action and knowledge are inseparably related. This consideration refers to a further feature of a human being's Dasein, 'existentiality', the apprehension of her purposive being and potential.

Dasein is also community. The modifications of the social environment or communal world (Mitwelt) are the 'authentic' (eigentlich ${ }^{10}$ - 'actual', 'essential'), unique being, recognisable and recognised among other human agents, and those who are merely present, who are mere (passive) existents, who constitute the conformist masses and banal averageness, with whom communication is not actually possible. 'Inauthenticity' refers to depersonalised mode of being, with no temporal significance other than that of sheer presence. This is intimately connected with a third feature of Dasein, (what Heidegger calls) 'fallenness' (Verfallen, Verfallensein), the individual's tendency to become lost in present preoccupations or to 'fall prey to' the average everyday roles imposed on her, forfeiting her unique possibilities and 'authentic' existence. Being there is not the same as being conscious (as implied in Descartes's cogito ${ }^{11}$ ): Dasein is the individual's ability to exist in the world, determined by the choices she makes, including false or 'inauthentic' ones.

Finally, Dasein is being-towards-death. This absolute limit gives rise to the actual significance and urgency of human Dasein: it asks each individual to live her life in freedom and responsibility. Death at once locates Dasein in time, makes it temporal/ finite (thereby giving it temporal significance), and gives rise to concern and care (Sorge). Sorge comprises the three characteristics of Dasein - facticity, existentiality and fallenness. A human being's particular mode of being-in-the-world (see also

8 The notion 'facticity' is broadly similar to 'factuality', but it is reserved essentially for Dasein, i.e. the sheer fact that one is.

9 However, Dasein 'exists' (i.e., 'stands forth'), creating its own ways of being, in a way that no other entity does. So, according to Heidegger, instead of speaking of 'categories', as we do when examining the being of other entities, we should speak rather of 'existentials', to mark the basic features of Dasein's being.

10 To be 'authentic' is to be true to one's 'own self', to be one's own person, to do one's own thing.

11 As Yun has pointed out (2018, p. 215), the Cartesian notion of the human being is that of a body-independent mind that is also "abstracted from experience". 
Yun, 2018, pp. 214-215) is characterised by relatedness to surrounding objects and members of her community, in terms of being concerned with and caring about them. As Inwood notes (1997, p. 58), "the only entities that lack care, concern, and solicitude are those that are wholly incapable of them, such as trees, stones, and animals".

Heidegger's magnum opus is Being and Time (Heidegger, 2001). Published in 1927 , it is not an explicitly or overtly political work. Yet, in a sense, as his letters and especially his Schwarze Hefte reveal, he draws on the worst anti-Semitic clichés of his time and embeds these in the ontological vocabulary developed in the 1920 . Heidegger's anti-Semitism is not ostensibly biologically based but ontohistorical. For him, Jews are not (in) Dasein, but only (in) 'that which exists' (das Seiende) - they are mere entities, merely present, mere passive existents, meaning they are not only 'inauthentic' but, in fact, seinsvergessen (oblivious of being), which for Heidegger is objectionable. He perceives them in connection with wheelings and dealings (Machenschaften) $^{12}$ that flatten, reckon up and exploit all that is (das Seiende; the being, the entity, what is, beings, entities) - and that progressively alienate us from being (Sein). According to him, Jews actively promote the abandonedness of being (Seinsverlassenheit) of the modern world, the uprootment of all that is present (das Seiende) from being (Sein). Heidegger's thinking here assumes conspiracy-theoretical proportions: whether it is Jews or technology, Machenschaft is omnipresent, an omnipotent ontic destiny, an anonymous 'will to power'. In the exploitation of all that exists, there is ultimately no difference between war and peace, only an all-out 'onslaught' (Angriff) - in Heidegger's overstrung apocalyptic diagnosis. Perhaps the argument might be made that Being and Time precedes the Schwarze Hefte and that, therefore, a distinction between Heidegger the philosopher and Heidegger the person is not only possible but mandatory. However, it is well-documented that his anti-Semitism was already firmly in place before he wrote Being and Time, and it is difficult reading the work today without bearing in mind the connotations of some of his ontological vocabulary that later became so glaringly and painfully obvious.

\section{Heidegger and philosophy of education}

Perhaps, at this juncture, I might be forgiven a personal confession: I find it very difficult to work up any degree of enthusiasm for Heidegger's philosophy. I cannot endorse his somewhat immodest appraisal of his own substantial contribution in this regard (in a letter dated 1 July 1916 he refers to his "philosophical gift"; Heidegger, 2008, p. 22). It seems to consist in the main of highly artificial and

12 This is already indicated in the aforementioned letter to Elfride on 20 August 1920 (Heidegger, 2008, p. 77). 
contrived Geschwurbel (educated babble) ${ }^{13}$, of bald assertions and verbal arbitration. He does not provide argumentation so much as seek to 'reveal': so perhaps his philosophy is, rather, a kind of ontomysticism that evades the thrust-and-parry of rational, scholarly disputation. Heidegger commonly seems to elevate etymological nitpicking and wordplay to the status of philosophy. His dismissal, in a letter to Elfride on Whit Sunday 1917, of Edmund Husserl's "narrow \& bloodless ... phenomenology" (Heidegger, 2008, p. 33) could just as easily be directed towards his own style of thinking and manner of articulation. From one particular perspective, his disdain for axioms and the basic rules of propositional logic and for the perfectly rational requirements that valid arguments must adhere to a certain form and that sound arguments must in addition satisfy certain criteria in terms of content renders his ideas unassailable. From a less charitable perspective, however, his Vernunftkritik comes across as the narcissistic reaction of someone whose rampant speculations would be held in check by critical, logical examination and interrogation. I suspect that fairly little would remain if one were to eliminate all invalid and unsound reasoning and all outlandish etymological testimony from Heidegger's writings.

I also struggle to see his relevance to philosophy of education ${ }^{14}$ that many have attested to, especially in recent years. Thus, in 2009 Michael Peters commented in an editorial dedicated to the significance of Heidegger's phenomenology for philosophy of education: "Heidegger and his forms of phenomenology have been a neglected figure in the field of philosophy of education in the English-speaking world. Little has been written on Heidegger or about his work and its significance for educational thought and practice." (Peters 2009, p. 1)

This has certainly changed in recent years, Heidegger's ontology and phenomenology being drawn on by Gloria Dall'Alba in her discussion of "professional ways of being" (Dall'Alba, 2009), Angus Brook in his account of coming to terms with becoming a teacher (Brook, 2009), Vasco D'Agnese in his discussion of truth as disclosure via education (D'Agnese, 2015) and of the ethics of teaching (D’Agnese, 2016; see also Lewis, 2017), SunInn Yun's analysis of time as a resource in education, as well as education as an existential event (Yun, 2018), and in discussions of the different possibilities of thinking in education (Bonnett, 1994; Lewin, 2015; Peters, 2007; Standish, 1992; Siegel, 2017 ${ }^{15}$; Williams, 2013; 2015).

13 A case in point is the near-incomprehensible (and almost certainly untranslatable) formulation of the "Schied als der fügenden Fuge der äußersten Freye zur Innigkeit des Selben Selber" (Heidegger, 2015). This is reminiscent of Lewis Carroll's Jabberwocky - albeit without the humour.

14 I concede, however, that the letters that deal with the politics of academia, both during and after the Third Reich, make for fascinating reading; see Heidegger, 2008.

15 In order to pre-empt any misunderstanding, it must be pointed out in this regard that Harvey Siegel does not pretend to be a Heidegger scholar. Indeed, he confesses to a "lack of familiarity with and understanding of Heidegger". In his article, he merely responds to Emma Williams's (2015) concern that Siegel's account of critical thinking is excessively tied to epistemology, and 
However, it should also be noted that Heidegger seems to understand infancy and childhood as a "privation of adulthood, by contrast with our fully fledged Dasein" (Inwood, 1997, p. 21). This clearly indicates a deficit conception of infancy and childhood, as something to get through and leave behind, as phases of development that exist only in instrumental terms of preparation for adult life, rather than being valuable and cherishable in and for themselves. Heidegger does not appear to have been very interested in education. There is very little in his work that relates to education, pedagogy, and child-rearing, and it would appear that it "serves more as an inspiration in rethinking the role and goal of education." (Yosef-Hassidim, 2014, p. 434) In other words, it contains no philosophy of education. For better or worse, it allows for unrestrained interpretation and extrapolation.

A possible exception may be the following passage from Heidegger's book What is called thinking?: "Teaching is more difficult than learning. We know that; but we rarely think about it. And why is teaching more difficult than learning? Not because the teacher must have a larger store of information, and have it always ready. Teaching is even more difficult than learning because what teaching calls for is this: to let learn. The real teacher, in fact, lets nothing else be learned than - learning. His conduct therefore often produces the impressions that we properly learn nothing from him, if by learning we now suddenly understand the procurement of useful information. The teacher is ahead of his apprentices in this alone, that he has still more to learn than they - he has to learn to let them learn. The teacher must be capable of being more teachable than the apprentices. The teacher is far less assured of his ground than those who learn are of theirs. If the relationship between the teacher and the taught is genuine, therefore, there is never a place in it for the know-it-all or the authoritative sway of the official. It is still an exalted matter, then, to become a teacher." (Heidegger, 1968, pp. 15-16)

The 'argument', then, that Heidegger provides is the following: Teaching involves letting learn, and indeed learning to let learn. Because of this, teaching is more difficult than learning. Therefore, to become a ("real") teacher is an exalted matter. But is the initial premise correct? And how does one get from the first assertion to the assertion that marks the sub-conclusion here? What constitutes the essence of teaching that allows learning to take place? What compliance or collusion on the part of the teacher does such teaching involve? How might conditions be established that are conducive to 'letting learn'? Heidegger does not elaborate on any of these matters. Must teachers be prepared to remain silent, and thus curb their inclinations to pass on their knowledge, information and ideas that have excited and continue to excite them? (It is not at all clear whether Heidegger heeded his own advice.) Finally, the notion of becoming a (real) teacher being "an exalted

to her argument that the work of Heidegger, for example, can be employed "in the development of a deeper, richer, 'radically different conception of thinking and the human being who thinks' [Williams 2015, p. 142]” (Siegel, 2017, pp. 193-194). 
matter" remains unexplained and thus, too, a mere assertion. The deliberately nebulous and ambiguous nature of many of Heidegger's ideas ${ }^{16}$ allows for all kinds of interpretation and extrapolation - which may help explain why so many philosophers of education claim to find in his work inspiration for rethinking the role(s) and goal(s) of education. There are many thinkers, philosophers other than Heidegger, who have expressed thoughts and ideas that are at once more immediately valuable, more obviously relevant to education, pedagogy, and childrearing, and considerably less banal.

My own misgivings about Heidegger's philosophical and educational significance notwithstanding, the proposal to think without Heidegger arguably constitutes advocacy of a kind of censorship that has no natural home in democratic, open-minded discourse. My counter-proposal is to embark on a much more critical approach to Heidegger (especially within English-language philosophy of education), and to re-think his purported contribution and relevance in the light of his ominous political and, indeed, philosophical leanings.

\section{References}

Blum, E. (2014, November). Die Marke Heidegger. Die Zeit, 46.

Bonnett, M. (1994). Children's Thinking. London: Cassell.

Brook, A. (2009). The Potentiality of Authenticity in Becoming a Teacher. Educational Philosophy and Theory, 41(1), 46-59.

Cammann, A., \& Soboczynski, A. (2016, October). Der Fall Heidegger. Die Zeit, 45,13 .

D’Agnese, V. (2015). The Inner (and Unavoidable?) Violence of Reason: Re-reading Heidegger via Education. Journal of Philosophy of Education, 49(3), 435-455.

D’Agnese, V. (2016). Facing Paradox Everyday: A Heideggerian Approach to the Ethics of Teaching. Ethics and Education, 11(2), 159-174.

Dall'Alba, G. (2009). Learning Professional Ways of Being: Ambiguities of Becoming. Educational Philosophy and Theory, 41(1), 34-45.

Di Cesare, D. (2015, June). Denken unter Polizeischutz. Die Zeit, 55.

Ettinger, E. (1995). Hannah Arendt - Martin Heidegger. New Haven \& London: Yale University Press.

Gerratana, V. (1977, November-December). Heidegger and Marx. New Left Review, $106,51-58$.

16 Take the aphoristic "Das Denken ist die Sage des Brauchs" (Heidegger 2015): 'die Sage' could be rendered as 'saga', 'myth' or 'rumour', but also as 'the saying' (or 'the presently verbally manifest'), while 'Brauch ' covers 'custom', 'convention' and 'use'. It is clearly one thing to refer to thinking as custom or use being presently verbally manifest and quite another to characterise it as a conventional or customary myth. 
Habermas, J. (1953, July). Mit Heidegger gegen Heidegger denken: Zur Veröffentlichung von Vorlesungen aus dem Jahre 1935. Frankfurter Allgemeine Zeitung, 170.

Heidegger, A. (2015, March). Der Vorwurf geht ins Leere. Die Zeit”, 52.

Heidegger, M. (1968). What is Called Thinking? (transl. J.G. Gray). New York: Harper \& Row.

Heidegger, M. (1983; orig. publ. 1934). Die Selbstbehauptung der deutschen Universität: Das Rektorat 1933-34. Frankfurt/Main: Vittorio Klostermann.

Heidegger, M. (2001; orig. publ. 1927). Sein und Zeit. Tübingen: Niemeyer-Verlag.

Heidegger, M. (2001). Being and Time (transl. J. McQuarrie \& E. Robinson; orig. publ. 1927). Oxford: Blackwell.

Heidegger, M. (2008). Letters to his Wife: 1915-1970 (ed. G. Heidegger; transl. R.D.V. Glasgow). Cambridge: Polity Press.

Heidegger, M. (2014a). Schwarze Hefte 1931-1938 (Überlegungen II-VI/Gesamtausgabe 94) (ed. P. Trawny). Frankfurt/Main: Klostermann.

Heidegger, M. (2014b). Schwarze Hefte 1938-1939 (Überlegungen VII-XI/ Gesamtausgabe 95) (ed. P. Trawny). Frankfurt/Main: Klostermann.

Heidegger, M. (2014c). Schwarze Hefte 1939-1941 (Überlegungen XII-XV/ Gesamtausgabe 96) (ed. P. Trawny). Frankfurt/Main: Klostermann.

Heidegger, M. (2015). Schwarze Hefte 1942-1948 (Anmerkungen I-V/Gesamtausgabe 97) (ed. P. Trawny). Frankfurt/Main: Klostermann.

Heil, D. (2011). Ontological Fundamentals for Ethical Management: Heidegger and the Corporate World. Dordrecht: Springer.

Heinz, M. (2015). Die geheimen Briefe. Hohe Luft, 3, 82-83.

Heinz, M., \& Kellerer, S. (2016). Martin Heideggers "Schwarze Hefte": Eine philosophisch-politische Debatte. Berlin: Suhrkamp.

Homolka, W., \& Heidegger, A. (Eds.) (2016). Heidegger und der Antisemitismus: Positionen im Widerstreit. Freiburg/Breisgau: Herder.

Inwood, M. (1997). Heidegger: A Very Short Introduction. Oxford: Oxford University Press.

Kellner, D. (1984). Herbert Marcuse and the Crisis of Marxism. London: Macmillan.

Lewin, D. (2015). Heidegger East and West: Philosophy as Educative Contemplation. Journal of Philosophy of Education, 49(2), 221-239.

Lewis, T. (2017). Study Time: Heidegger and the Temporality of Education. Journal of Philosophy of Education, 51(1), 230-247.

Neiman, S. (2016, October). Die Quelle allen Unglücks? Die Zeit”, 49.

Noll, A.J. (2016). Der rechte Werkmeister: Martin Heidegger nach den "Schwarzen Heften". Cologne: PapyRossa Verlag.

Peters, M. (2007). Kinds of Thinking, Styles of Reasoning. Educational Philosophy and Theory, 39(4), 350-363.

Peters, M. (2009). Editorial: Heidegger, Phenomenology, Education. Educational Philosophy and Theory, 41(1), 1-6. 
Probst, M. (2015, April). Der Philosophen-Streit: Wer kann ihm folgen? Die Zeit, 65. Siegel, H. (2017). Epistemology in Excess?: A Response to Williams. Journal of Philosophy of Education, 51(1), 193-213.

Standish, P. (1992). Beyond the Self: Wittgenstein, Heidegger and the Limits of Language. Aldershot: Ashgate.

Trewhela, P. (2008, March). Two Vice-Chancellors: Heidegger and Makgoba. PoliticsWeb. Retrieved from http://www.politicsweb.co.za/news-and-analysis/ two-vicechancellors-heidegger-and-makgoba

Vašek, T. (2014). Ein totalitärer Denker. Hohe Luft, 6, 68-76.

Vašek, T. (2015). Heideggers heiliger Krieg. Hohe Luft, 3, 70-74.

Vašek, T., \& Figal, G. (2015). Das ist der Tod der Philosophie. Hohe Luft, 3, 80-81. Vašek, T., \& Marten, R. (2015). Heidegger denkt gegen das Leben. Hohe Luft, 3, 75-78. Vašek, T., Marten, R., \& Trawny, P. (2017). Was bleibt von Heidegger? Hohe Luft, 2, 60-64.

Williams, E. (2013). 'Ahead of All Beaten Tracks': Ryle, Heidegger and the Ways of Thinking. Journal of Philosophy of Education", 47(1), 53-70.

Williams, E. (2015). In Excess of Epistemology: Siegel, Taylor, Heidegger and the Conditions of Thought. Journal of Philosophy of Education, 49(1), 142-160.

Yosef-Hassidim, D. (2014). Rethinking Education: Heidegger's Philosophy in the Service of Education. Philosophy of Education. Retrieved from https://ojs.education.illinois.edu/index.php/pes/article/view/4904/1535

Yun, S.I. (2018). Heidegger and the Recovery of Education. In P. Smeyers (Ed.). International Handbook of Philosophy of Education (pp. 211-224). Cham: Springer.

\section{MYŚLENIE BEZ HEIDEGGERA?}

Streszczenie: W ostatnich latach nastąpiło odrodzenie zainteresowania myślą Martina Heideggera, zwłaszcza w anglojęzycznej filozofii wychowania. Jednak były też inne wydarzenia, które zasługują na poważne potraktowanie, przede wszystkim wykazujące, że jego antysemityzm informuje nie tylko o jego osobistych przekonaniach i stanowisku politycznym, ale jest głęboko zakorzeniony w jego filozofii, zwłaszcza w ontologii. To właśnie te zmiany i kontekst filozofii Heideggera zostaną zbadane na początku niniejszego artykułu. Następnie autor odniesie się do rzekomego przełomowego znaczenia jego spojrzenia na wychowanie.

Słowa kluczowe: antysemityzm, etnonacjonalizm, Martin Heidegger, filozofia wychowania.

Kai Horsthemke is an Associate Professor and teaches philosophy of education at KU Eichstätt-Ingolstadt in Germany. He is also a Visiting Professor in the School of Education at the University of the Witwatersrand, South Africa, and a Fellow at the Oxford Centre for Animal Ethics, UK. Since 2004, he has published extensively on African philosophy, indigenous knowledge systems, and animal ethics. He is the author of three books: The Moral 
Status and Rights of Animals (Porcupine Press, 2010), Animals and African Ethics (Palgrave Macmillan, 2015), and Animal Rights Education (Palgrave Macmillan, 2018), and also the co-editor of Education Studies (Oxford University Press South Africa, 2013 and 2016 [2nd ed.]). E-Mail-address: Kai.Horsthemke@ku.de. 